\title{
Discussion on the Problems in Operation of Changsha Yongzhi Logistics and the Countermeasures
}

\author{
Shijun Yuan \\ Hunan Modern Logistics College \\ Changsha, China
}

\begin{abstract}
The development of logistics industry in Changsha is still in initial stage. The backward logistics situation will undoubtedly become a "bottleneck" of the economic development. How to combine Changsha's reality, give play to its advantages, accelerate the development of Changsha Yongzhi Logistics, and further promote the rapid growth of the city's economy becomes an issue to be solved urgently. Over an objective analysis on the current situation of Changsha Yongzhi Logistics, this paper gives some rough views on the operation of Xiangyun.
\end{abstract}

\section{Keywords—concept; talent; informationization}

\section{INTRODUCTION}

With the all-round advancement of economic integration in Changsha, Zhuzhou and Xiangtan, the expansion of economic aggregate, and the enlarging of influence, Changsha has already entered the radioactive range of the Changsha-Zhuzhou-Xiangtan economic circle. Personnel communication between Changsha, Zhuzhou, Xiangtan and Yiyang becomes more and more frequent, the economic and trade relationship becomes increasingly close, and the complementary function becomes more and more prominent. However, the development of logistics has also been greatly improved; Changsha Yongzhi Logistics is facing enormous challenge and also an excellent opportunity.

\section{GENERAL INFORMATION OF THE COMPANY}

Changsha Yongzhi Logistics Company has 86 employees, more than 230 specialized transportation vehicles (wherein, there are 26 special LTL vehicles and 2 local distribution vehicles), 11 express transportation centers, more than 1200 $\mathrm{m}^{2}$ of in-service LTL warehouse, $9000 \mathrm{~m}^{2}$ of in-service parking space, $30000 \mathrm{~m}^{2}$ of warehouse under construction, and $80000 \mathrm{~m}^{2}$ of parking space under construction, with total land area reaching $1000 \mathrm{mu}$. It is a road freight transportation, distribution, warehousing, packaging, loading and unloading, information, auto repair, guest house and other functions integrated third-party logistics company.

\section{ANALYSIS ON PROBLEMS EXISTING IN THE COMPANY'S DEVELOPMENT}

\section{A. Rigid and Lagging Thoughts and Ideas}

In cognition, there are still many misunderstandings of modern logistics; in thoughts, modern logistics hasn't been paid enough attention to; the overall benefit of the logistics system is ignored to some extent. Moreover, the company has weak awareness of logistics service, hasn't formed the concept of "the essence of logistics is service", but merely treats logistics work as a kind of labor work. The shipper often gives customer cold shoulder; the delivery driver is often lazy and late, and often runs the red light, carries private goods and even maliciously talks with the consignee; a small number of employees are often not well-dressed and do not treat the goods carefully.

\section{B. Low Quality of Logistics}

The company is in such status as small scale, not that high credibility, only a few professional personnel, and low quality, with service level to be further improved, as well as single service function, not so many transportation networks, low degree of integration, and limited technical service power. Given the single transportation and warehousing, it is rarely able to provide logistics planning and organization service, conduct a full-process management on the supply chain deepening into the enterprise's production field, and even provide customers with extraordinary value-added services as per customers' demands. Since there is no unified logistics management department, the management on logistics enterprises is neglected, so that the credibility cannot be guaranteed. The disorder the logistics market has had a bad impact on Changsha's economic development. It is imperative for Changsha to develop modern logistics industry, normalize and rectify the logistics market. At the same time, logistics industry in Changsha cannot match with the requirements of modern logistics due to the insufficient investment in relevant construction and the lagged facilities. Warehousing, transportation and distribution and other parts are still operated manually, lack of an effective logistics information platform and a sound logistics operation network. Given the inability to optimize the scheduling and make effective allocation, most enterprises are still in the state of one-way full load and temporary distribution in return trip. 


\section{Low Degree of Informationization}

The level of informationization is relatively low. There are a large number of enterprises, scattered resources and excessive market competition. There is also neither a sound service network and information system, nor a good information-based system to support it. At present, most of customers are still contacted by telephone and fax, causing high operating cost; the means and channels of information management are backward; and the social information network has not yet been established; up to now, there is no information exchange platform for logistics exchange in Changsha. Enterprises fail to realize information technology management, so that there is lack of carrier for application of modern information technology in the society and also lack of applicable information exchange platform for logistics. In this circumstance, users can neither make orders on the Internet as per their own needs, make online selection and payment, nor search and track the progress of their goods at any time; the supply and demand information cannot be circulated in both directions in time. The low level of informationization directly restricts the development of enterprise and also affects the business development of enterprise.

\section{Seriously Insufficient Logistics Talents}

Professional talents are needed to support the development of modern logistics industry. As an industrial concept, modern logistics is just known by people, and is greatly restricted in cultivation and output of relevant talents. Moreover, few companies can truly realize complete modern logistics activity, and the actual logistics operation experience is insufficient. In the whole society, there is a shortage of logistics talents, especially those who both have professional theories and are proficient in information technology and logistics management. With respect to Xiangyun Changsha Company, a large-scale logistics enterprise in Changsha, its talents are mainly recruited from vocational secondary schools. Although they have certain cultural quality, there is still a certain gap compared with professional logistics talents. The lack of logistics talents is an important factor restricting the development of logistics enterprises, which brings certain difficulties to the rapid development of logistics industry.

\section{DISCUSSION ON COUNTERMEASURES FOR LOGISTICS OPERATION OF THE ENTERPRISE}

\section{A. Service Specialization}

Service specialization at least includes specialization in scope and function and specialization in service object. The main service contents include: the first service content is logistics plan, including logistics planning and model design, making case analysis as per customer needs and designing unique and appropriate logistics planning solutions for customers to support and meet the needs of customers' sustainable development. The second service content is logistics operation management, including the management on transportation, warehousing, loading and unloading, packaging, sorting and tallying to normalize the business operation management system and the operational standards of business department, as well as specifying the settings and functions of business operation administrator, operation posts and the duties, operation work classification and operation work flow, the standard operation process of various works and the evaluation method for various works. The third service content is logistics information, including information system planning, information technology support, and information management to provide real-time and accurate information services for dual supervision on the logistics process by both company and the customer.

\section{B. Improving the Speed and Quality of Logistics Services}

Starting from the reform inside company, it is necessary to build a sense of service among extensive employees and make clear that the essence of third-party logistics enterprise is to provide service. Specific service should be provided to satisfy customer's different demand.

\section{Developing Strategic Alliances and Implementing Intensive Operation}

Logistics alliance is centered on itself and combined with other enterprises and third-party logistics agencies to form an intensive logistics partnership with mutual trust and sharing risks and benefits to get scattered logistics achieving scaled economic and logistics efficiencies; wherein, a number of small and medium-sized enterprises are incorporated into the alliance in form of entering agreement. The logistics processes of different commodities are not only spatially contradictory, but may also be overlapped in time. Enterprises can solve those problems of contradiction and overlapping through intensive processing of third-party logistics agency. Alliance members can not only share risk, reduce risk and uncertainty, but also obtain excess logistics capabilities and strong logistics management capabilities from third-party logistics agency.

\section{Vigorously Carrying out Value-added Services}

Being innovative, out of routine, and satisfying customer needs are essential features of value-added logistics services. The types of value-added services that can be carried out include carrier-based value-added service, warehouse-based value-added services, information-based value-added services, and financial value-added service, and so on. Through efficient value-added services, it is not only conducive to expanding the business scope of the company, discovering new profit points, but also helping to establish long-term and stable partnership with customers.

\section{E. Corresponding Government May Take Its Overall Advantages to Participate in the Competition}

With the rapid development of economy, Changsha Yongzhi Logistics is both in face of opportunities and new challenges. On the one hand, foreign logistics enterprises have entered the logistics market of the city, which has intensified the competition in the logistics industry; on the other hand, due to small scale and scattered management, Changsha Yongzhi Logistics is difficult to compete with large-scale logistics enterprise groups from places beyond 
the city. For example, the goods of large industrial and commercial enterprises such as Nice are monopolized by logistics companies from places beyond the city; the goods of large chain supermarkets such as BBK and Your-Mart are also distributed by the headquarters; rare local logistics companies in Changsha are involved in their goods distribution. This is unfavorable to the development of Xiangyun. Consequently, local resources are lost and the enterprise's development is weakened; however, the railway and waterway resources with low transport cost are heavily set aside and their capacities are not fully utilized. Therefore, Xiangyun also has competitive advantages in terms of speed, cost and management. Xiangyun Group Changsha Company actively raised funds, and the Transportation Department also allocated 5 million Yuan to supplement some of its construction funds. However, the project still has a $30 \%$ funding gap; hence the government is needed to give active support and guidance, provide preferential policies, and introduce foreign capital to ensure completion of the project as scheduled.

\section{F. Actively Using Hi-tech Logistics Equipment and Improving Logistics Management Technology}

While actively developing logistics, it is necessary to vigorously promote the application of computers, information technology, and develop special vehicles, advanced loading and unloading and warehousing technologies. A basic feature of modern logistics industry is logistics information and e-commerce services based on Internet and electronic data exchange platforms. Operation of modern logistics industry depends on logistics information platform. Accordingly, it is needed to accelerate the construction of "Digital Changsha" and encourage and support communication enterprises to achieve integration with the Changsha-Zhuzhou-Xiangtan Information Network, as well as construct a shared logistics information center platform across the city and e-commerce integrated service platform as soon as possible, and build up an efficient, quick and sound logistics information service system to enhance the collection, processing and operation of logistics information. Through this platform, goods transportation enterprises, processing trade enterprises, circulation enterprises, customs, taxation, banks and other units and departments in the logistics chain can be connected to realize the sharing of logistics information and logistics functions. Responsible person of Changsha Company of Xiangyun Group said that it is hoped that the government can invest in the establishment of an information platform. This reflects the enterprise's urgent need for constructing a logistics information platform.

\section{G. Strengthening the Cultivation of Logistics Technical Talents and Management Talents}

Given that logistics industry started late in China, logistics talents are extremely lacking and are the core and key to the development of modern logistics. It is proposed to recruit a number of outstanding logistics talents from other cities to settle in Xiangyun; those talents must have certain foresight, strong logical thinking ability and strong communication skills, master relevant professional knowledge of mathematics, accounting, computer, etc. and can make decisions quickly in understanding orders, shipping goods, transportation, and other works. Further, the existing technicians should be provided with extensive training to get them aligned with large third-party logistics talents. This is to further boost the rapid development of logistics industry.

\section{CONCLUSION}

The development of third-party logistics is a systematic project. It is far from enough to only depend on single efforts of logistics enterprises the logistics enterprises to make their own efforts. It also needs the promotion and regulation of the government and industrial associations, in order to create a good external environment for enterprise development. Wherein, government and industrial associations should do the following points: first, it is necessary to establish and improve corresponding policy and regulation system as soon as possible, especially the formulation and implementation of preferential policies, to provided regulatory basis for development; second, it is necessary to establish normative industrial standards as soon as possible, implement industrial self-discipline, and standardize market behaviors to provide rules for operation of logistics business; third, it is necessary to play their organizational, coordinative, and planning functions, make unified planning and rational layout, and establish a modern logistics center with multiple functions, high level, strong concentration and distribution function and wide scope, to overcome the drawbacks of fragmentation, avoid repeated construction and waste of resources, and promote the healthy and orderly development of third-party logistics. For enterprise, it is needed to combine with its specific conditions and improve its core competitiveness, creatively develop its own logistics business, expand the market, improve the business level, and provide customers with all-round and high-quality logistics services.

\section{REFERENCES}

[1] Wen Zhenhua, Huang Hui. Introduction to Modern Logistics [M] Hunan People's Publishing House, 2007. (in Chinese)

[2] Zhou Chikai. Research on the Innovation of Enterprise Logistics Management Mode under the Background of "Internet+" [J]. Journal of Jiamusi Vocational Institute. 2018(07). (in Chinese)

[3] Wen Zhang. Improving the economic ability of high-quality logistics service entity [J]. China Tendering. 2019 (17). (in Chinese) 